\title{
「高砂寮」(戦後の「清華寮」)関連記事 一『台湾日日新報』より一
}

\section{横路啓子}

ه024668@mail.fju.edu.tw

\section{一、歴史の証人としての高砂寮}

廃墟に魅力を感じる者は決して少なくはない。そうした廃墟マニアの中で名 が知られているものの一つに、東京文京区苔荷谷の清華寮がある。「清華寮」で検 索すれば、荒れ果てておどろおどろしい画像がヒットする。この建物は、戦後そ の所有権が宙に浮いたまま、台湾人や中国人によって自治管理が行われ、1950年 代には台湾人の密航の際の中継地になっていた。またバブル全盛期の 2000 年前後 には、東京の一等地にある所有者不明の地であるために、この土地をめぐって詐 欺まがいの事件が起きている。さらに、2007年7月19日には火災が発生し2人が死 亡、2013年5月には解体工事が行われ、現在は更地となっている。すでに失われ てしまったとはいえ、この寮は日本と台湾の歴史を語る上で貴重な証人である。

戦後、清華寮と称されたこの寮は、戦前「高砂寮」と呼ばれていたものであ る。1911年に東洋協会専門学校(拓殖大学の前身)に隣接する小石川区茗荷谷町に 建設され、台湾人(本島人)留学生を収容していた。当初、運営していたのは台湾 総督府だったが、その後、実質的には台湾協会や台湾総督府の関係団体である学 租財団が管理運営をするようになる。寮建設の目的の一つは、台湾人留学生の経 済的な負担を減らすほかに、彼らが危険な思想に染まらないよう管理するた めであった。しかし、その思惑がそれほど功をなしていなかったことを当時の メディアは伝えている。1920年代、東アジアで最も進んだ都市「東京」へ留学し ていた台湾青年たちは、大学でデモクラシ一や共産主義といった新思潮に触れつ つ、台湾にはないさまざまな先進的な文化に触れ、自由の空気を吸っていたの である。台湾留学生が台湾へもたらした思想は、台湾思想史の中で最も重要な部 分となり、そしてまた戦後、国民党による新たな統治(といっていいのであれ 
ば)に遭った際の抵抗のよりどころともなった。こうした台湾青年たちにとって の重要なトポスとして高砂寮があったのである。

戦後、清華寮となった後については比較的調べやすいが、戦前の高砂寮はど のようなものであったのかはあまり知られていない。このため、ここでは以下 において高砂寮関連の年表を挙げ、その後日本統治時代の台湾で最大部数を誇っ ていた『台湾日日新報』からそれに関する記事を拾っていく。それは現在ネット 上で戦後の廃墟の姿をさらすだけになってしまったこの寮において、戦前どれ ほど生き生きとした活動が行われていたのかを現わしていくためである。この ため、記事は主に彼らの生活ぶりや寮内の様子がわかるものを選んだ(『台湾日日 新報』の記事であるため、どうしても台湾総督府の宣伝の意味合いが強いものと はなっているが)。なお、記事にはもともとルビがふってあるが、これは省き、 強調されているところは原典どおり傍点を施した。判読不能だった文字は、 を用いた。

\section{二、高砂寮年表(資料元の $(*)$ は本稿の第三節に転載してあるもの $)^{1}$}

1 年表作成にあたって は、紀旭峰『大正期台 湾人の「日本留学」研究』 (龍溪書舎，2012年）を 参考にした。

2 台湾総督府史料編纂会 『台湾史料稿本』。

3 加藤春城『台湾教育沿革 誌』(台湾教育会, 1939 年).

4 宮川次郎『高砂寮問題』 （台北市：拓殖通信社， 1928年)

\begin{tabular}{|c|c|c|}
\hline 年月 & 出来事 & 資料元 \\
\hline 1911年 & $\begin{array}{l}\text { 東洋協会幹事長門田正経が東京に台湾人留学生用の寮 } \\
\text { を建設することとを台湾総督府に提言。 }\end{array}$ & $\begin{array}{l}\text { 『台湾日日新報』(以下『台日』) } 1912 \\
\text { 年11月29日 }(*)\end{array}$ \\
\hline 1912年9月 & 9日、高砂寮落成。 & $\begin{array}{l}\text { 「本島人内地留学生ノ寄宿舍建設」 } \\
\text { 『台湾史料稿本』 } 21912 \text { 年2月9日 }(*) \\
\text { 『台湾教育沿革誌』3 }\end{array}$ \\
\hline 1912年11月 & $\begin{array}{l}\text { 高砂寮開寮(小石川区茗荷谷町三十二)。経費は学租財 } \\
\text { 団が負担。 } \\
\text { 18日、高砂寮規則を制定。 }\end{array}$ & $\begin{array}{l}\text { 『台日』1912年11月29日 ( *) } \\
\text { 『台湾教育沿革誌』 }\end{array}$ \\
\hline 1912年11月 & 台湾国語学校生徒歓迎会を開催。 & 『東洋時報』247(1919) \\
\hline 1913年9月 & $\begin{array}{l}\text { 台湾総督府農業試験場生徒農科2年生20名ほどが高砂 } \\
\text { 寮に宿泊。 }\end{array}$ & 『東洋時報』180(1913)。 \\
\hline 1915年7月 & 20日新渡戸稲造が「台湾学生の為に」と題し講演する。 & 『東洋時報』202(1915) \\
\hline 1918年6月 & 民政長官下村宏来寮。 & 『台日』1920年4月1日 ( *) \\
\hline 1919年5月 & $\begin{array}{l}\text { 18日、吉野作造が内ケ崎作三郎と共に来寮し講演す } \\
\text { る。 }\end{array}$ & $\begin{array}{l}\text { 吉野作造『吉野作造選集14：日記2』 } \\
\text { 岩波書店、1996年 }\end{array}$ \\
\hline 1920年3月 & 台湾総督田健治郎来寮。 & 『台日』1920年4月1日 ( *) \\
\hline $\begin{array}{l}\text { 1920年10月 } \\
\text { 24日 }\end{array}$ & $\begin{array}{l}\text { 寮生である黄土水が帝展に入選、その祝賀会を高砂寮 } \\
\text { で開催。 }\end{array}$ & 『台日』1920年10月26日 \\
\hline 1921年7月 & $\begin{array}{l}\text { 寮生の思想問題により、7月末日で高砂寮閉鎖、入寮 } \\
\text { 者は帰台した。 }\end{array}$ & 『台日』1921年6月7日 \\
\hline 1921年9月 & 高砂寮再開、新寮長は佐藤寅太郎。 & 『台日』1921年8月8日及び10月19日 (*) \\
\hline 1923年9月 & 関東大震災で高砂寮も被害を受ける。 & $\begin{array}{l}\text { 『台湾教育沿革誌』 } \\
\text { 『台日』1923年9月7日及び9月14日 }\end{array}$ \\
\hline
\end{tabular}




\begin{tabular}{|c|c|c|}
\hline 年月 & 出来事 & 資料元 \\
\hline 1923年12月 & $\begin{array}{l}\text { 関東大震災への台湾島内からの義捐金から20万円を高 } \\
\text { 砂寮の復旧費にあてることを決定。 }\end{array}$ & 『台日』1923年12月29日 (*) \\
\hline 1925年4月 & 新高砂寮竣工。 & 『台湾教育沿革誌』 \\
\hline 1925年7月 & $\begin{array}{l}\text { 新高砂寮完成。しかし経費(寮の維持費など)の問題な } \\
\text { どから正式な開寮は見送りとなる。 }\end{array}$ & $\begin{array}{l}\text { 『台日』1925年7月3日 }(*) \text { 及び9月 } \\
\text { 23日 }\end{array}$ \\
\hline 1925年9月 & $\begin{array}{l}\text { 19日、台湾青年会幹部が抗議のために高砂寮生ととも } \\
\text { に寮の乗っ取りを計画する。 }\end{array}$ & 『台湾教育沿革誌』 \\
\hline 1925年10月 & $\begin{array}{l}\text { 25日、神田青年会館で台湾青年会臨時総会を実施、高 } \\
\text { 砂寮自治会組織を決議する。 }\end{array}$ & 『台湾教育沿革誌』 \\
\hline 1927年6月 & 学租財団が経営を引き継ぐ。 & 『台湾教育沿革誌』 \\
\hline 1927年7月 & $\begin{array}{l}\text { 高砂寮の問題が解決、7月29日、石黒文教局長が関係 } \\
\text { 者十数名を上野精養軒に招待し慰労会を開催。 }\end{array}$ & 『台日』1927年7月31日 \\
\hline 1927年10月 & 9日、新高砂寮開寮式。これに伴い旧寮は閉鎖される。 & 『台日』1927年10月5日及び10月10日 \\
\hline 1928年3月 & 上旬、入寮生が食事に対して抗議のハンストを実施。 & 『台日』1928年3月7日 ( *) \\
\hline 1928年3月 & $\begin{array}{l}\text { 10日、寮生70名余りが中村寮長を袋吅きにする「高砂寮 } \\
\text { 事件」が勃発、中村寮長は全治1ヶ月、駆け付けた刑事 } 2 \\
\text { 人も2階から突き落とされ重軽傷を負った。 } \\
\text { 15日、この事件が台湾留学生に伝わり、台湾青年会主催 } \\
\text { で高砂寮欠食事件批判大会が神田明治会館で行われる。 }\end{array}$ & $\begin{array}{l}\text { 『台日』1928年3月12日 }(*) \\
\text { 『高砂寮問題』4 }\end{array}$ \\
\hline 1930年11月 & $\begin{array}{l}\text { 50余名の寮生が一部生徒の煽動により、全員退寮し、 } \\
\text { 寮が開鎖となる。 }\end{array}$ & $\begin{array}{l}\text { 『台湾教育沿革誌』 } \\
\text { 『台日』1932年1月20日 }\end{array}$ \\
\hline 1932年1月 & 高砂寮再開決定。寮長は佐藤寅太郎。 & 『台日』1932年1月20日 \\
\hline 1932年4月 & $\begin{array}{l}\text { 元台北第一師範学校教諭の張福興に補助金を交付し経 } \\
\text { 営を委託し、再び開寮。 }\end{array}$ & 『台湾教育沿革誌』 \\
\hline 1933年3月 & 末日、張福興の一身上の都合により、委託を解き、再び閉鎤 & 『台湾教育沿革誌』 \\
\hline 1935年10月 & $\begin{array}{l}\text { 財団法人修養園 (代表者医学博士二木謙三) に補助金を } \\
\text { 付与し、経営を委託、これによて開。 }\end{array}$ & 『台湾教育沿革誌』 \\
\hline 1938年5月 & 23日、高砂寮再開の記念日を祝う式を開催。 & 『台日』1938年5月24日 \\
\hline 1953年6月 & $\begin{array}{l}\text { 清華寮 (=高砂寮)が台湾から中国への中継地点となっ } \\
\text { ていることが発覚、昭和医大に留学中だった台湾人学 } \\
\text { 生羅鴻文が逮捕される。 }\end{array}$ & 『読売新聞』1953年6月30日 \\
\hline 1988年4月 & $\begin{array}{l}\text { 清華寮所在の国有地の払い下げ詐欺事件。これによっ } \\
\text { て清華寮の所有権が注目されることになる。 }\end{array}$ & $\begin{array}{l}\text { 『読売新聞』1988年4月8日、12日及 } \\
\text { び13日 }\end{array}$ \\
\hline 2006年?月 & $\begin{array}{l}\text { 清華寮の所有者が文部科学省認可の財団法人「進徳奨学 } \\
\text { 会」に決定。 }\end{array}$ & 『読売新聞』2007年5月30日 \\
\hline 2007年5月 & $\begin{array}{l}\text { 29日、東京都が寮の家屋部分の固定資産税課税を進徳奨 } \\
\text { 学会に通知することを決定。また敷地所有者の国が進徳 } \\
\text { 奖学会に対し土地明け渡しを求める訴訟準備を進める。 }\end{array}$ & 『読売新聞』2007年5月30日 \\
\hline 2007年7月 & 19日、出火で2人死亡、7人が軽傷を負った。 & 『読売新聞』2007年7月19日 \\
\hline 2007年10月 & $\begin{array}{l}\text { 架空の清華寮開発話による詐欺事件、容疑者3人が逮 } \\
\text { 捕される。 }\end{array}$ & 『読売新聞』2007年10月11日 \\
\hline 2013年4月 & 清華寮が撤去される。 & \\
\hline
\end{tabular}




\section{三、『台湾日日新報』の高砂寮関連記事}

\section{2年11月29日朝刊2面 風雷坊「台湾学生寄宿舎}

台湾留学生の数は年々増加して現今では実に百五十名内外の多数に上つて居る のであるが、是等在京学生の大部分は弊風多き下宿生活をして居る、元来下宿屋 なるものは言子迄もなく営利一天榐りの業務であるから在宿者が堕落しやう と何うしやうと、そんな事は更に関はぬ、たぶ金になりさへすればそれで宜し いのである、同時に在宿者は金を払ひさへすればどんな真似でも仕たい放題の 事が出来る、従つて其処に種々の弊風が生ずるのは不思議はない。年々地方から 上京する学生が、中途にして志を擲ち堕落の淵に沈むのは此の下宿屋なるものが 興つて大に力のあるのである。未だ思想固まらざる青年を斯る処に預けて置く事 は恰も火薬を抱いて火中に入ると一般、此上なき危険千万の事と云ふべきであ る、台湾留学生の大多数も亦斯る危険なる生活を学んで居るのである。

そこで東洋協会幹事長の門田正経氏が規律ある生活を為さしめ、質素勤勉真面 目なる学生を養成し以て留学の目的を達せしめやうと云ふ趣旨から、昨年渡台の 折台湾の官紳に諮り大賛成を得て遂に総督府をして台湾留学生の寄宿舎を建てし むるに至つたのが、此処に紹介する高砂寮である。寮は東洋協会専門学校に隣接 せる(小石川区茗荷谷町三二) 高燥閑雅の地であつて緑樹四辺を巡らし殊に楓林、 桜梅の花樹に富み、従つて空気も清く衛生に適し寄宿舎として此上なき好適地で ある。

高砂寮は本年五月工を起し工費一万五千余円を投じ八月末竣成し、九月十五日 から開館する事になつて、本寮の特色とする処は第一建築壮麗にして内部の整頓 して居る事である、階下は自修室、事務室等に充て階上は寝室になつて居る、自 修室は椅子、卓子を備へ付けて一室八人詰の十一室、内一室は特別自修室として ある、寝室は日本間で一室十人詰の八室から成つて居る、此外に食堂、浴室、小 使室等も完備して居る、食事も台湾料理を喰はせる事になつて居るから、此点丈 けでも非常な仕合せと云ふべきである、其上に宿料は僅に八円の食費丈けで宜し いのであるから経費の点に於ても下宿屋に比べると少くも五、六円若くは七八円 は廉い即ち普通下宿屋の半額で済む訳だ

舎内の取締りの為め舎監二名を置てある、一名は教育家で一名は文学士だ、将 来は舎内で特別教授を施し又は毎月講演会を開いて名家の講演を請ひ、若くは学 生の智識交換の為め演説会を開き、其他内地の習慣を習はす為めに講礼会若くは 親睦会の様なものを時々催す事になつて居る。入寮生の定員は八十名だが今日の 処では二十名分丈けを収容して居るに過ぎないが、本来の方針亡して成うべくな らば未だ内地の悪風に染まざる新留学生を收容する事を希望して居る。兔も角も 斯る完備せる寄宿舎の出来た以上は父兄は安心して其の子弟を留学せしむる事が 出来る訳で台湾留学生の福音を云ふべきである。 


\section{5年4月20日朝刊3面「高砂寮の近沉 本島人の東京留学生は何んな生活をして居る」}

東京中の台湾学生は、現在約二百名ばかりある。而して其一切の監督は小石川 区苔荷谷町三十二番地なる台湾総督府学生監督所が掌つて居る。高砂寮は、則ち 之と同一建物で、等しく学生監督所の管掌するものになつて居る。此一切の監督 は、東洋協会の門田正経君が任じ、寮長には文学士後藤朝太郎君が任じ、主事の 中村甚八郎、主事補の林邦彦両君が専ら之を助けて居る。即ち台湾留学生を別て ば、寮内生と寮外生になる。此寮内外の学生を集めて一つにしたものが、高砂青 年会であつて此幹事長は、台南出身の人で文科大学で哲学の専攻中の林茂生君が 任じてるる。高砂寮も元は可なり大勢の学生がるたけれど、監督の厳重と、規則 づくめの煩頊に耐へ難い結果か、現在では柔順な、温良な、良成績のものばかり が、十七八名残つて居る。

以上寮内生を庁別にすると、台中庁が十一名、嘉義庁が四名、台北庁が二名、 台南庁が一名、南投庁が一名、更に之を学校別にすると、東洋商業が三名、慶応 の商工科が一名、大成中学が一名、明治中学が一名、立教中学が二名、海域中学 が一名、正則英語学校が三名、明治薬学校、日本中学、独逸協会中学、渡辺学館 其他一名といふ事になる。此うち台南庁から来て、此寮に起臥してるた柯丁丑君 はつい此間東京音楽学校を卒業して、已に帰島して居るので、寮の娛楽部備品で ある楽器は、楽手其人を失つたから、此春は空しく塵に埋れて沈然をつぶけてる る。

寮生は交る ぐ \娛楽部や、食事部や運動部の幹事をやつて、就食事の献立 は、衆議によつて、一週間分宛が議事されては其れが食堂へ張り出されると云ふ 立憲的、其上、食堂の一隅には食事の批評といふノートと鉛筆が具へてあつて各 自の意見を述べてある。振つたものの一二をいふなら、『更に野菜を加へて鿓ひ たい』カツレツは一週二回以上なるを要す』味噌汁に肉の少量は遺憾千万也』な どの類である。

主事の談に拠ると、時間の励行は実に驚くべき程厳格で、殆んど時計が不必 要な位である。其机ばかりでない、寮内で盜難が第一にない。自分のものは自 分のものでよく始末をして、決して他と貸し借りをしない、其上舎官監や主事 や、監督が彼是れ世話をやかんでも独りでにずん/入自習する。夜は舎監や、 主事や、其他の人々が学校以外の事を日本語で教へるかたはら教へたり、種々の 注意を与へて居るが、欠点をいへば、嘘をつく事である。平気で嘘をついて、 其れを当然と思つてるる一事である

寮の階上は寝室になつてるて、一室が日本風の十八畳、此一隅に十四五の錠前 つきの押入れがあつて数字の番号を記し、そして各人の専用を示して置くが、鍵 は一つ/入異るものが用ひられてある。唯だ此押入れと限らず寮内に鍵といふ 鍵のある処で、一つでも同一の鍵は用ひてるないさうだ。舎監室は二階の寝室へ 昇つて、突当る正面 $\square$ それで庁が中央になり、此左右にかの十八畳から成る寝室 
が、五つ六つ並んで居る

自習室は階下である、之も左右に廊下を隔て〉、五六人宛の学生が自習しう る如く寝室とは反対に洋式になつて椅子テーブル式で、入口の一側に其人名札が かけてある。中へ入つてつい立があつてそれへ帽子や、袴や、外套その他が掛 つて居る。机は向き合せに五六並べてあり、中央に折からの花など活けて極め て瀟酒風雅な中で彼らの勉学は $\square$ 今続けられて居る。応接室には魏陳思曹植の詞 で梁鵠の書いた孔子廟の碑の石刷の軸と、魏魯郡太守張府君清頌碑の同軸とが掛 けてあつても、台湾臭 $\square$ 寮内には少しもせん。娛楽室としての図書室、遊戯室見 るからに綺麗で、如何にもなが／入しいもの>配置と装飾である。

高砂寮は台湾総督府が一切の台湾留学生を監督指導すべく新築したもので巳に 之が為に三万円あまりも投じて居るさうだ。本島人学生であつて、内地の学校に 入るには庁長なり、支庁長なりの証明書を携へて或は単独に来つて此寮内なる台 湾学生監督所の紹介書を鿓はねば、内地の学校では受附けない。其処で先づ入学 紹介書下附願といふものを寮内なる台湾総督府学生監督所へ差出して許可になる と、今度は希望の学校へ宛てた同監督門田正経君の記名捺印した紹介書を渡され る事になる。さうして現在では、百八十六人といふ本島人留学生が、約七十校大 体次のやうな東京市内の学校に入学しつつある。

$\boldsymbol{\Delta}$ 中学の部 京北、正則、郁文館、目白、清城、 $\square$ 天、開成、大成、立教、明 治、日本、独逸協会、京華

A商工学校の部 京華商業、東洋商業、大倉商業、京北実業、慶応商工

外に慶応の普通部、明治学院の普通部、正則英語、明治薬学などがあれど、小 学在学者が、亦可なりある。其校名は

小石川で明化、礫川の二小学、赤坂で中の町小学、青山の $\square$ 小学、京橋で明石 小学、牛込で市ヶ谷、山吹の二小学、芝で白金小学、靝町で暁星小学

右の合同したものが、即ち『高砂青年会』なのである。而して、少々毛色の変 つた学校へ入つママてるものをいふと、人員は極めて少くて、学習院在学中の林 一家なる林熊祥、林熊光、林崇智、林履信の四君と、麻布獣医畜産学校の嘉義庁 下庄仔口街の蘇求氏と、府立演芸学校の、台北大稲埕建昌街の鍾耀廷君位なとこ ろ、女学生も亦至て少く、今の処十名以上はないらしい。然らば、此成績は如何 にといふに、一般の支那留学生や、朝鮮留学生よりも、素行の点に就いては比較 的立派で、勉強もするけれど、どう云ふものか、監督所の親切な世話を、往々に 束縛する意味に解したり、干渉する意味に解したりして困らせる

用事があつて、監督所から手紙を出て来いと言つても、多くは宿所を換へる 事が頻繁で、いつも至急の間に合はない。其ればかりでない、学校を能く換へ るばかりでなく、他人にも其れを勧誘して、甲から乙へ、乙から丙へと云ふ如 く、学校を取換へる事と、下宿屋を取換へる事が余りに平気すぎる。其上二度 や、三度の呼び出し状で、直に監督所である高砂寮へ来るものは、今の処殆んど 
ないらしい。

口之ならず、どんな事に対しても、先づ疑つて見る、其うして、よくノ窮 めた上でなくば決心を容易にしない風があるので、当業者は、いつも/入手古 摺つて居る。寮に居ても、平生の行動中、立ち聞き、密話等に趣味を持つ癖があ つて困る。さうして、内地人は、どうして我我をこんなに、干渉するだらう位 に考えてるて困るさうである。以上は留学生といつた処で、官費生ではない、 何れも父兄からの仕送りによつて留学中のものを、台湾総督府が、東洋協会と合 カして、特に世話を焼くといふのが、即ち高砂寮と、其学生と、此寮内の監督所 監督の学生連であつて、現在の東京には先づ此以外の台湾留学生はないらしい。 其の将来性に就いては、留学生を内地へ遣す処の父兄に記者の註文が大にあるけ

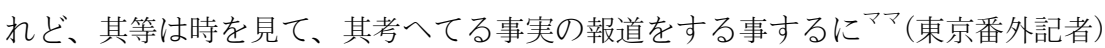

\section{0年4月1日朝刊3面「田総督 高砂寮学生と愁談せらる」}

口般本紙電報欄にて報道せられた如く田総督は東京市小石川区茗荷谷町在寮台 湾学生寄宿舎高砂寮を視察せられた当日田総督には川崎内務局長、鼓参事官及び 喜多秘書官を随へられ永田台湾学生監督の案内にて来寮された、寮側にては後藤 高砂寮長を始め主事並に五十名の在寮学生は玄関先に出迎へ一同紀念のため写真 を撮つた、応接室に小憩の後監督には寮生及び寮外生を合はせて七十余名を引見 された、その際豊島師範生徒游覚(彰化出身)が寮生を代表して鄭重なる挨拶を述 べ次いで蔡式穀(新竹出身)は学生一同を代表して日頃の述懐希望を縷々告白し た、これに対して総督は諒々と左の訓示を与へられた、その大要は

自分は本島人教育に就いては将来共学と為すの方針を以て漸次其準備を進め之が 実現を速にせん事を希望して居ることは既に一部の人士の間には承知されて居る事で ある、最近父兄側に於いても家庭教師を迎へ或は幼稚園を新設するとか、種々の方法 を設けて児女の国語練習に力を用ひ内地児童と共学せんことを期して居る様である諸 子は誘惑の多き東京に留学中の事であれば申寸迄もなく素行を慎み意志を強固にして 取り返しのつかぬ邪道に陥らざるやう日夕注意しなくてはならない諸子の一挙一動 は台湾父兄並びに郷党全般に多大の影響を及ぼす者であるから各自自重して留学生の 名誉を毀損せぬ丈けの覚悟を要する而して思想を堅実にし学事に勉励し各自学業を卒 へ帰台の後は台湾文化の発展に貢献して貪ひたい総督府にても思想が堅実で且有用の 人材であればこれを適所に採用する事に客ならず自分自身も平素その辺の考を有つて 台湾の将来を思うて居る

総督の訓辞終へて総督一行は寮内階上の各寝室階下の各自修室、入浴場及び食 堂など一々巡視せられた現今五百名に近き在寮留学生を保護し年々多数の入寮申 込者を収容するには現在の設備のみにてはあまり狭险を覚えて居る殊に物価騰貴 の関係上最近入寮希望者益々激増して来た学寮はその為めに年来計画されて居る 
隣接の高砂寮拡張予定地約一千坪の事なども総督の前で話が出で総督には高砂寮 階上よりその地所を眺められた、また応接室にては寮生の製作品として東京美術 学校卒業期生黄土水の木彫 (林熊光愛蔵大理石作外三点)を陳列したるが台湾から 既にこれほどまでの美術家が出て居るかと少からず賞讃された事であつた、大 正七年六月下村長官が来寮の事はあつたが、高砂寮に総督の来られて殊に親しく

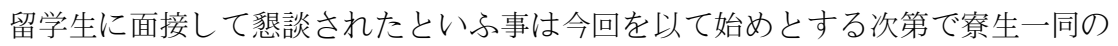
歓喜は非常な者ママであつて紀念写真の焼増配布を希望するものが続出して写真に 羽がついて飛ぶ勢で買はれて居る、因みに高砂寮の拡張計画は長官其他の同意を 得て辜顕栄、顔雲年、林献堂の諸名家には夫久寄附の申出でがある、尚ほ寄附者 の氏名は之を紀念碑に刻し永く其芳志を伝へる計画となつて居る(高砂寮報告)

1921年6月9日朝刊7面「高砂寮の解散 涙を振つて馬䅰を斬つた 総督府の英断 学生が政治運動に盲動するは 殷鑑遠からず其弊を支那に見よ」

高砂寮閉鎖に就ては既報の如くなるが更に聞く所に依れば去月三十日同寮寄宿 の台湾学生中硬派と目せらる>約三十名を東洋協会楼上に招致し同寮閉鎖の旨言 ひ渡せる際の如きは学生中には閉鎖の理由を明らかにせざれば同寮を退去せずと の硬強論を唱ふるものあり或は何等かの方法を講じ依然現在の儘居残らん事を主 張する向きもあり所説紛々たりしが其翌日は俄然形勢一変、事茲に到りたる以上 は所詮此の儘居残る事の不可能なるを悟り七月の期日を待たず全部同寮を引払ふ 事に決せる由にて既に渋谷平岡吉子方の二階を始め七八名の学生は外泊せんとい ふ、事の茲に至れる理由は彼等が総督府の意志に反したる行動を執りたる事屡々 にて少しも反省の模様見えざるのみならず近来高砂寮は政治運動其他の策源地な るやの観あり斯くては同寮設立の目的を達する能はざるを以て寧ろ之を閉鎖する に如かずといふに在るもの>如し而して今回総督府が右の決定を為すに至りたる 最近の出来事は従来同寮は食費每月一人十六円を徵し舎費としては何ら徵する所 なかりしが斯くては維持費等に多額の費用を要するを以て今回舎費として毎月一 人五円宛を徵収する事を申渡せるに彼等学生は之に応ぜるのみならず反対に従来 の食費十六円を十二円に引下ぐべしと迫り飽くまで強硬に之を主張せるを以て総 督府側に於ては最早彼等に説諭を試むるも改悛の意志なしと見て取り茲に右の如 き最後の手段に出でたるものなりといふ、而して今後の処置に就ては目下東洋協 会と打合中なるが多分総督府は同寮を其の管轄外に置き東洋協会に於ては一切の 事業を引継ぎ其の内容に多少改善を加へ経営するならんといふ(七日東京発)

1921年10月19日朝刊7面「民営になつた東京 高砂寮の団欒 六十名の台湾学生 が一家族となつて佐藤寮長の下」

【東京特電】茲に総督府の手から東洋協会に引き継ぎ、所謂民営事業となつた 小石川の高砂寮は佐藤寮長就任以来、内部の諸設備に改善を加ふると共に、九月 
一日から台湾学生の収容に着手したが、両三日前に至り設備を改善すると共に定 員六十名の学生満員となり昨夜五時半から同寮食堂に於て、祝賀の意味に於て水 入らずの晚餐会を催した定刻学生一同食堂に参集し協会側から永田理事、佐藤寮 長、春山、江上監督等列席先づ佐藤寮長は寮長就任の由来及び設備改善の詳細に 瓦り縷述した後、

一千余哩遠しとせず父母の許を離れ、遥々東京に留学し此一堂に会せる諸君は実 に一箇の大家族である、予は之を自治的に養育し度い考へであるから諸君は互に相戒 め互助的観念を以て、善く和衰協同し、自ら解決する得ざる事故若しくは病気等のあ つた場合は、隔意無く監督に訴へ、又よく其命を守り、斯くて台湾出発の際に於ける 覚悟と精神を飽く迄覆へす事なくよく勉励し一日も早く所期の成功を遂げられん事を 望む

と恰も慈父の愛児を諭すが如く講演説示する処があつた、次で永田理事今回 寮の組織内容を一新したるを機とし、茲に諸君と相見るは予の最も欣快とする処 なり、諸君は寮長以下の意を体し互に相助け、勉励以て、故郷に錦を飾られん事 を望む

との意味を述べ、終はつて各自談笑中に食事を執り六時十分一旦休櫋六時半か ら茶話会を開き茶菓を喫しつ>又佐藤寮長から台湾学生志望に対する同情談あ り、春山氏よりは寮内規則改正に関する披露をなすと共に之が励行を促し次で学 生等一同に姓名原籍学校名等を夫れ夫れ個人に紹介をなさしめたが、中には紹介 の序でに娛楽場運動場の設備等につき滑稽交りに愛嬌的希望を述べて茶目くる者 あり其都笑声講堂に満ち一家団欒の気分に一同を醉はしめた斯くて六時十分和気 藹々哩に解散し一同は各自寝室に引き上げたが之より先き記者は各室を参観し た、其構造の要を示すると学生を収容すべき部屋十二あり何れも二十四冨を敷き 得べき広間で、之を二分し一方に十二睤の畳を敷きて $\square$ 所となし、他方にはリ， リウムを敷き詰め机椅子を並べて自修所となしあり、一室五人宛を定員とする又 別に約二十畳を敷く特別自修室あり同寮の消灯時間は夜十時なので其後の勉強者 の為めに設けたものである此外学生用としては病室、娛楽室あり病室は入院の必 要無き程度の患者の療養所で薬品其他医療用具数種を用意整頓して居る

娛楽室には新聞、雑誌及び碁、将棋の類を備へ其他風呂場、食堂等美なりと云 ふを得ざるも風通よく清潔で総て理想的に設備し殆んど惜然する処が無い食物の 如きも学生としては充分足るを思はしむ

その食費一箇月十四円舎費に円合計十六円之を十円内外の間借自炊生活乃至三 十五円内外を支払子下宿生活に比せば第一勉学監督の点に於て其の他食物衛生金 銭の浪費等の諸点に於て如何に彼等台湾学生等の幸福なるかを思はしめるのであ る(十七日発) 


\section{3年12月29日朝刊5面「義捐金の中から 二十万円を割いて 高砂寮復旧費とする」}

関東地方義捐金に関し総督府では二十五日発起人会を開き種々協議の結果、台 湾関係の罹災学生の為めに義捐金四百十三万二千七十五円四銭の中から二十万円 以内を支出して現在の高砂寮を復旧し且つ之が拡張を測る事に決し

一、震災義捐金中二十万円以内を割て台湾関係学生の寄宿を建築すること

一、右金額の決定及び使用方法は総務長官に一任すること

を決議し直ちに在京の賀来総務長官に電報した、が義捐金中から罹災学生の為 めに右の金額を支出するに就ては在京各関係方面の了解も得、賞勲局に於ても亦 救護事務局へ送付の義捐金と同様の取扱をすることに決定して居ると尚義捐金中 是迄の諸支払は震災直後三井の手を経て物資を送つた、金が十八万三千四百四十 六円八十八銭外に運搬その他諸掛費五千五百円五十九銭計十八万八千九百四十七円 二十七銭、差引残金百二十四万三千百二十七円七十七銭であるが利子も既に約九 千円からに上つてるると

1925年7月3日夕刊2面「近く開館する 新高砂寮 壮大なる白亜の大建築 東洋一 の学生寄宿舎」

大正十二年の関東大震災によつて生れた東京小石川なる台湾学生寄宿舎新高砂 寮は大正十三年六月起工同十四年二月竣成を告げ、今や其壮大なる白亜の大建築 は鉄道ヶ原の丘上高く毅然として建ち、あたりを睥睨してるる、此新寮が震災に よつて出来たといふ理由は、従来高等専門学校以上の所謂青年に属する台湾学生 は高砂寮外の民家に散宿して居たのであるが彼の大震災によつて殆ど悉く居所を 失ひ他の罹災者と同様憫むべき境遇に陥つたのである、そこであの当時まだ一般 市民の居宅も出来揃はなかつた際の事で、台湾として之等居所を失つた学生の救 済は急務中の急務であつた、此処に於て時の台湾当局は大に之を憂慮し震災地救 助寄付金の内より約二十万円を割き之れを以て新高砂寮建設の計画を立てたので あつた、斯くて新高砂寮は去る二月竣成したのであるが当局としては之れが経営 方針及び維持方法等を考慮しなければならぬので直に開寮といふ段取りにはなら なかつたのであるが、訳を知らない幼年の学生達は一日も早く新寮舎に入りたい とねだるし、旁々当局に於ても種々考慮を進めた結果愈々旬日出ずして開寮期決 定の運びとなつた模様である。新寮舎は森山技師の設計監督の下に建設されたも のであるが、総建坪五百三十七坪三層楼鉄筋コンクリートの堂々たるものであ る、正面の大玄関を入ると直ぐ其処は長方形の大広間で悠に五百名を入れ得る天 井は屋根まで打ち抜き硝子張りとしたので光線は充分に室内を輝らし読書に何等 の不自由を感じない、二階三階の内廊下には大広間に添うて頑丈な手摺を着けて あるから通行に何等の危険なく議会の傍聴席と言つた形で、何等の催物の場合は 此階上廊下を傍聴席に充つれば将に一千人を収容し得る、此処は時折講演会や活 動写真などをやる目論見であるらしい、此大広間を中心として其周囲の一階には 
事務室、学生の勉強室、食堂、談話室、小使室及び寮長の住宅などに充て二階三 階は全部学生の勉強室及び寝室になつて居る、家具其他諸設備は全部洋式を採用 し便所の便器まで洋式のものを用るて居るが寝室には特に日本式の畳を敷込んで ある、之れは旧寮の方も同様であるが内台の交際は永久であり益久密接であら称 ばならぬといふ所から畳に馴れしむる必要を認めたものであらう、旧寮の方で は勉強室と寝室は同一室内に設けてあるが新寮では此二つは全々別になつて居て 勉強室の椅子テーブルの如き頗る分厚な頑丈な良材を用る二又塗りで素晴しく立 派に出来て居る、此勉強室十四寝室は十二冨敷十六畳敷取り混ぜ十三室、収容定 員八十四名といふのである、此処には又地下室があつて其処には賄人部屋、料理 部屋、浴室、ボイラー室がある、此ボイラー室から各室にチユーブを通じス チーム暖房装置があり又料理部屋からは階上食堂に飲食物を運ぶエレベタ一の仕 掛けあるなど一見大ホテルの観があり学生寄宿舎としては東洋一を誇る理想的の ものである、更に屋上に上れば平坦百七十六坪の見晴し台をなし附近の建物を眼 下に見下し遠くは九段山上の靖国神社、本郷山の其他郡部の山久は勿論品川沖の 遠望又佳なりである、此屋上に電気動力を以て水を引上げ洗濯場の設備があるか ら思ふ存分の納涼と衣類の洗濯が出来て何時もさつぱりした気分で居られる、此 処に入寮する学生は全く果報者だ。翻つて旧寮の方はどうかといれば之れ又門の 附換へをなすと共に食堂浴場其他の造り変へをなしペンキですつくママり塗り上 げたのだから従来とは見違へる程立派になつた其上今度は一室に二人宛 (現在は 一室三人)収容する事になるらしいから余程居心地よくなる筈である、然し何ん と言つても新建の立派な宿舎に入り度いのが人情で学生中暗々裏に新寮舎入を競 争して居る模様であるが元来高砂寮なるものは幼年者保護の意味で建てられたの であるから新寮舎の方には中等学校程度以下の少年級を入れるのが穏当であらう と謂はれて居る

1928年3月7日朝刊5面「高砂寮の台湾学生 欠食同盟を断行 試験中にも拘はら ず 不良分子の煽動から」

【東京支局特電六日発】高砂寮新設会館以来静肃であつた台湾学生は一部不良 分子に煽動され昨朝来欠食(中には絶食せりと伝へる者あるも誤り)を断行してる る其の真相に就て聞く所に依れば同僚の賄方は台湾人邱君が引受けて居り学生等 は毎月賄料として十五円宛支払ひおるが学生中に不良分子数名混入し居り彼等は 定食以外に贅沢なる料理を註文し二円乃至八、九円の借金を抜へてるる邱君がこ れを催促するとこれを支払はないのみか却て賄方を恨み食糧粗悪なりと覀罵して 器具を破壊する事の事屡々あり善良なる学生を誘惑し遂に今回の挙に出でたもの である中村寮長は

目下学生の多くは試験中にあり勉強の最も必要なる時期に拘らず理由なき欠食を 
あへてするは甚だ不都合である殊に台湾学生に対しては長官、局長共に非常の同情を 寄せられ困難であつた暖炉其他の設備にも不自由無く完成せしめられた今日誠に見に くい不平の為に特更に食糧の不良呼りを為しか〉る暴挙をなさ様にと懇々説諭した

之にも拘らず例の不良分子等が炊事当番に当つた折から肉の生煮のあつたの を機会に欠食を断行したものである寮長は寮規を乱し寮内を攪乱するものとし情 に於て忍びざるも万やむを得ざるものとして台中州彰化出身陸木松以下八名に対 し三日以内に退寮を命じたが在京青年会幹部に於ては当局の意の存する所を諒と し斡旋の労を取りつ> ある欠食を断行せる学生等は目下寮外の飲食店にて食事を 為しつ>あるが寮内に於ては一日五十銭を要し経費の膨張と勉強時間空費等に後 悔し居る向も多数ある模様なれば発頭人八名の退寮処分を以て一段落を告ぐるや に観測されてるる

1928年3月12日夕刊2面「高砂寮の寮生七十餘 名中村寮長を袋吒き 全治一箇月 の重傷を負はせ 刑事二名を二階から突落し之亦負傷 首謀者七名検挙さる」

【東京特電十一日発】小石川茗荷谷台湾総督府経営寄宿舎高砂寮に於ける賄排 斥運動の首謀者八名の学生に対して退寮を命じたが依然として二階に立籠り不穏 の形成があるので十日夜八時頃中村寮長が同室に赴いて退寮を命ずると他の七十 名ばかりの学生が鐘をならし中村寮長を取巻いて袋吅きにし全治一箇月の重傷を 負はせたこの騒ぎに予て警戒中の大塚署の大林小畑両刑事が取調べに向ふと何れ も二階から突き落されて打撲裂傷を負ふたが応援警官出張首謀者林某外六名を検 束取調中である。

横路啓子 Keiko YOKOJI

(台湾) 輔仁大学外国語学部日本語文学科。准教授。日本統治時代の台湾文学、日中比較文 化など。『抵抗のメタファー一植民地台湾戦争期の文学』(奈良：東洋思想研究所, 2013), 『文學的流離與回歸 - 三0年代郷文學論戰』(台北：聯合文學出版社, 2009)。 